\title{
UPAYA MENINGKATKAN HASIL BELAJAR FISIKA MENGGUNAKAN PENDEKATAN CONTEXTUAL TEACHING LEARNING PADA MATA PELAJARAN FISIKA DI KELAS X-III SMA NEGERI 12 MEDAN TAHUN AJARAN 2012/2013
}

\author{
RAMZAH RAM \\ Guru Sekolah Menengah Atas Negeri 12 Medan \\ ramzahram@gmail.com
}

\begin{abstract}
ABSTRAK
Upaya meningkatakan hasil belajar fisika menggunakan metode Contextual Teaching Learning pada mata pelajaran fisika telah dilakukan. Subjek dalam penelitian ini adalah siswa kelas X-III yang berjumlah 30 siswa, sedangkan objek dalam penelitian ini adalah metode Contextual Teaching Learning, dan alat yang digunakan untuk mengumpulkan data adalah tes hasil belajar.

Berdasarkan tes awal (pre test) yang dilakukan terhadap 30 siswa terdapat 27 orang (90\%) siswa yang mendapatkan hasil belajar rendah (belum tuntas) dan belum mencapai KKM 70 dan sebanyak 3 orang siswa (10\%) yang termasuk dalam kategori tuntas. Kemudian pada siklus I terdapat 10 orang siswa $(33,33 \%)$ yang termasuk pada kategori tuntas dan sebanyak 20 orang siswa $(66,66 \%)$ termasuk dalam kategori rendah. Pada siklus II terdapat 23 orang siswa $(76,66 \%)$ termasuk dalam kategori tuntas, sebanyak 7 orang siswa $(23,33 \%)$ termasuk dalam kategori rendah (belum tuntas.

Berdasarkan hasil penelitiaan dari pre test dan post tes siklus I serta post tes siklus II sudah terjadi peningkatan yang signifikan yaitu sebesar 43,27\%. Hal ini menunjukkan bahwa dengan penerapkan metode Contextual Teaching Learning dapat meningkatkan hasil belajar siswa pada pelajaran Fisika pokok bahasan konsep kalor di kelas X-III SMA Negeri 12 Medan tahun ajaran 2012/2013.
\end{abstract}

Kata kunci: Kalor, PTK, Contextual Teaching Learning, Hasil Belajar 


\section{PENDAHULUAN}

Masalah yang dihadapi pendidikan adalah masalah lembaga proses pembelajaran. Dalam proses pembelajaran anak kurang didorong untuk mengembangkan kemampuan berpikirnya, untuk itu guru dituntut harus mampu mengelola proses belajar mengajar yang memberikan rangsangan kepada siswa karena siswa lah yang menjadi subjek utama dalam belajar.

Belajar merupakan kunci keberhasilan siswa, artinya belajar memegang peran penting dalam upaya meningkatkan hasil belajar siswa yang berkualitas memiliki karakteristik tertentu seperti wawasan pengetahuan yang luas, kemampuan untuk menyelesaikan permasalahan permasalahan sehari-hari yang dihadapinya, sikap dan perilaku positif terhadap lingkungan sosial maupun lingkungan alam sekitar. Sehingga belajar dapat lebih bermakna dan mudah dipahami oleh siswa dengan menggunakan berbagai metode.

Metode adalah cara yang dipergunakan untuk mencapai tujuan yang telah ditetapkan. Dalam kegiatan belajar mengajar metode sangat diperlukan oleh guru dan penggunaannya bervariasi sesuai dengan tujuan yang ingin dicapai setelah pengajaran berakhir. Seorang guru tidak akan dapat melaksanakan tugasnya bila dia tidak menguasai satu pun metode mengajar yang dirumuskan dan dikemukakan para ahli psikologi dan pendidikan (Djamarah dkk, 2006:72). Jika guru dapat menggunakan metode secara optimal dan mengaitkan materi pelajaran dengan lingkungan sekitar siswa maka siswa akan termotivasi dan hasil belajar siswa akan meningkat.

Berdasarkan pengamatan penulis di lapangan menyatakan bahwa hasil belajar siswa dikategorikan masih rendah karena siswa kurang termotivasi dalam belajar. Terbukti pada kenyataannya siswa kurang menyukai mata pelajaran IPA karena metode yang digunakan guru kurang bervariasi dan lebih banyak menggunakan metode yang sifatnya monoton.

Hal ini dapat dilihat dari nilai raport yang diperoleh dari guru kelas X-III. Nilai yang diperoleh siswa tidak mencapai KKM yaitu 72. Siswa yang tidak mencapai KKM sebanyak 80\% dari 30 siswa yaitu 24 siswa, sedangkan yang mencapai KKM sebanyak 20\% dari 30 siswa yaitu 6 siswa. Hal ini disebabkan karena siswa kurang dilatih berpikir kritis, kreatif, dan inovatif sehingga hasil belajar siswa rendah dan metode yang digunakan guru dalam pembelajaran Fisika kurang bervariasi. Guru cenderung menggunakan metode ceramah tanpa disertai dengan penggunaan media sehingga siswa cenderung pasif terhadap materi yang dijelaskan guru. Kepasifan siswa dalam belajar merupakan pertanda kurang baik dalam proses pembelajaran juga dalam perkembangan intelektual siswa. Siswa menjadi malas belajar, berfikir dan malas berkompetensi saat belajar sehingga akan mengakibatkan terciptanya siswa yang tidak terampil serta berintelektual dalam pembelajaran Fisika. Siswa harus berpikir kritis, kreatif, dan inovatif 
karena IPA adalah bidang studi yang mempelajari, menelaah, menganalisis gejala serta masalah alam di masyarakat dengan meninjau dari berbagai aspek kehidupan di masyarakat. Adapun kompetensi dasar dari materi yang akan diteliti yaitu memahami konsep kalor.

Untuk mencapai pengajaran yang baik, seorang guru dituntut untuk mampu memilih dan menggunakan metode pembelajaran yang sesuai dengan materi yang diajarkan kepada peserta didik. Maka salah satu cara dalam mencapai tujuan tersebut yaitu menggunakan pendekatan Contextual Teaching Learning pada pokok bahasan konsep kalor. Pada saat mengajar guru mengaitkan materi dengan situasi nyata siswa kemudian guru menugaskan siswa berdasarkan kelompok untuk mendiskusikan tentang materi. Dalam diskusi kelompok siswa diharapkan aktif dalam belajar. Berdasarkan pemahaman siswa terhadap pelajaran, siswa diharapkan dapat mengembangkan keterampilannya.

\section{Rumusan Masalah}

Adapun rumusan masalah dalam penelitian ini adalah "Apakah dengan menggunakan pendekatan Contextual Teaching Learning CTL) dapat meningkatkan hasil belajar siswa pada pokok bahasan memahami konsep kalor di kelas X-III SMA Negeri 12 Medan tahun ajaran 2012/2013?"
Tujuan Penelitian

Adapun tujuan penelitian ini adalah: "Untuk mengetahui apakah dengan menerapkan pendekatan Contextual Teaching Learning (CTL) dapat meningkatkan hasil belajar siswa pada memahami konsep kalor di kelas X-III SMA Negeri 12 Medan Tahun Ajaran 2012/2013"

\section{Langkah-langkah Pembelajaran Contextual Teaching Learning}

Menurut Jhonson, 2009 menyatakan bahawa langkah-langkah yang harus ditempuh dalam Contextual Teaching Learning adalah sebagai berikut:

1. Kembangkan pemikiran bahwa anak akan belajar lebih bermakna dengan cara bekerja sendiri, menemukan sendiri dan mengkonstruksi sendiri pengetahuan dan keterampilan barunya.

2. Laksanakan kegiatan inkuiri untuk mencapai kompetensi yang diinginkan di semua bidang studi.

3. Bertanya sebagai alat belajar: kembangkan sifat ingin tahu siswa dengan bertanya.

4. Ciptakan 'masyarakat belajar' (belajar dalam kelompokkelompok).

5. Tunjukkan 'model' sebagai contoh pembelajaran (benda-benda, guru, siswa, karya inovasi, dan lain-lain).

6. Lakukan refleksi di akhir pertemuan agar siswa 'merasa' bahwa hari ini mereka belajar sesuatu.

7. Lakukan penilaian yang sebenarnya: dari berbagai sumber dengan berbagai cara. 


\section{Hipotesis Tindakan}

Dari kajian teori dan rumusan masalah maka hipotesis tindakan dalam penelitian ini adalah, "Penerapan pendekatan CTL dapat meningkatkan hasil belajar siswa pada pokok bahasan memahami konsep kalor di kelas X-III SMA Negeri 12 Medan tahun ajaran 2012/2013”.

\section{METODE PENELITIAN}

Jenis penelitian yang dilaksanakan adalah Penelitian Tindakan Kelas (PTK). Penelitian ini memiliki beberapa tahap yang berupa siklus. Prosedur penelitian terdiri dari dua siklus, setiap siklus I dan Siklus II. Penelitian tindakan kelas (PTK) akan dilaksanakan di kelas X-III SMA Negeri 12 Medan. Subjek penelitian adalah siswa kelas X-III yang berjumlah 30 siswa. Penelitian ini akan dilaksanakan selama 3 bulan (mulai kesiapan mengajar sampai pelaksanaan tindakan) pada bulan Maret, April, Mei tahun ajaran 2012/2013.

Objek penelitian adalah CTL. CTL adalah suatu proses pembelajaran yang bertujuan untuk membantu siswa memahami makna yang ada pada bahan ajar yang mereka pelajari dengan menghubungkan pelajaran dalam konteks kehidupan sehariharinya dengan konteks kehidupan pribadi, dan sosial.

\section{Desain dan Prosedur Penelitian}

Sesuai dengan jenis penelitian ini, yaitu penelitian tindakan kelas maka peneliti menggunakan 2 siklus. Masing-masing siklus terdiri dari 4 tahap yaitu perencanaan, pelaksanaan, pengamatan dan refleksi.

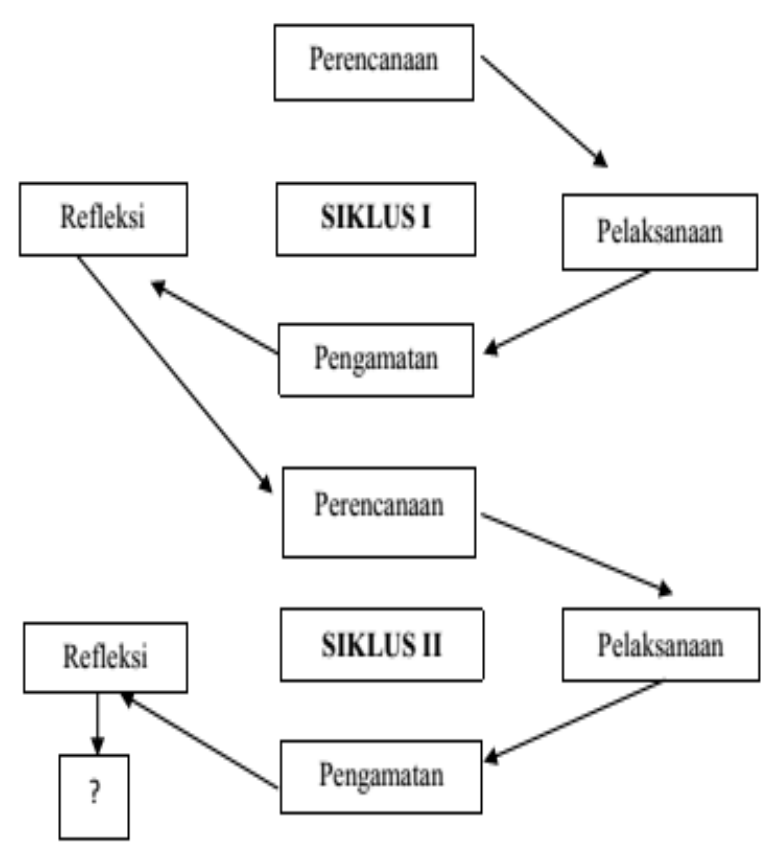

Gambar 1. Model Desain Tindakan Kelas Kemmis (dalam Arikunto, dkk., 2006)

\section{Teknik Analisis Data}

\section{Hasil Belajar Siswa}

Analisis ini dilakukan untuk mengetahui peningkatan hasil belajar siswa dengan penerapan pendekatan pembelajaran Contextual Teaching Learning atau berhasil tidaknya tindakan yang dilakukan, untuk mengetahui peningkatan hasil belajar siswa terhadap materi pelajaran dapat digunakan rumus (Arikunto, 2006):

$$
\mathrm{Sk}=\mathrm{B} \cdot \frac{\mathrm{S}}{\mathrm{O}-1}
$$

Sk = Skor yang diperoleh

$\mathrm{B}=$ Jawaban yang benar

$\mathrm{S}=$ Jawaban yang salah

$\mathrm{O}=$ Kemungkinan jawaban yang benar

Dalam penelitian ini guru menjumlahkan nilai yang diperoleh seluruh siswa kemudian dibagikan 
dengan jumlah siswa sehingga diperoleh nilai rata-rata.

Nilai rata-rata ini dapat dihitung dengan menggunakan rumus (Arikunto, 2006) :

$$
\bar{X}=\frac{\sum X}{\sum N}
$$

Keterangan :

$\bar{X}=$ nilai rat $a_{-}$rata

$\sum X=$ jumlah semua nilai siswa
$\sum_{N=\text { jumlah }}$ siswa

Untuk mengetahui ketuntasan belajar siswa, digunakan rumus sebagai berikut:

$$
p=\frac{\sum \text { jumlah siswa y ang tuntas }}{\sum \text { jumlah seluruh siswa }} \times 100 \%
$$

Kriteria tingkat keberhasilan belajar siswa dalam \% menurut Aqib (2008:41) adalah:

\begin{tabular}{|c|c|}
\hline $\begin{array}{c}\text { Tingkat Keberhasilan } \\
(\%)\end{array}$ & Arti \\
\hline$>80 \%$ & Sangat tinggi \\
$60-79 \%$ & Tinggi \\
$40-59 \%$ & Sedang \\
$20-39 \%$ & Rendah \\
$<20 \%$ & Sangat rendah \\
\hline
\end{tabular}

\section{Observasi}

Observasi untuk guru dilakukan saat guru mengajar di kelas dan observasi untuk siswa dilakukan pada saat proses belajar mengajar. Cara menganalisis hasil observasi guru yaitu dengan menggunakan rumus (Arikunto, 2006):
Nilai $=\frac{\text { jumlah skor yang diperoleh }}{\text { jumlah skor maksimal }} \times 100 \%$

\section{HASIL PENELITIAN}

Untuk mengetahui tingkat presentasi dari ketuntasan klasikal maka dapat dilihat pada Tabel 1 . dibawah ini:

Tabel 1. Tingkat Ketuntasan Klasikal Tes Awal

\begin{tabular}{|c|c|c|c|}
\hline No & Nilai & $\begin{array}{c}\text { Jlh. } \\
\text { Siswa }\end{array}$ & (\%) \\
\hline 1 & 0,67 & 6 & 20,00 \\
\hline 2 & 2,00 & 8 & 26,66 \\
\hline 3 & 3,34 & 5 & 16,66 \\
\hline 4 & 4,67 & 3 & 10,00 \\
\hline 5 & 6,00 & 5 & 16,66 \\
\hline 6 & 7,34 & 3 & 10,00 \\
\hline \multicolumn{2}{|c|}{ Jumlah } & 30 & 100 \\
\hline
\end{tabular}

Dari hasil jawaban siswa pada tes awal, menunjukkan bahwa siswa masih mengalami kesulitan dalam menyelesaikan soal-soal materi memahami konsep kalor, untuk itu perlu dilanjutkan ke siklus I.

Berikut ini disajikan persentase nilai siswa pada pos tes siklus I. Analisis data tentang ketuntasan belajar siswa dapat dilihat pada Tabel 2. berikut ini:

Tabel 2. Nilai Pos Tes Siklus I

\begin{tabular}{|c|c|c|c|}
\hline No & Nilai & $\begin{array}{c}\text { Jumlah } \\
\text { Siswa }\end{array}$ & Persentase (\%) \\
\hline 1. & 3,34 & 6 & 20,00 \\
\hline 2. & 4,67 & 9 & 30,00 \\
\hline 3. & 6,00 & 3 & 10,00 \\
\hline 4. & 7.34 & 10 & 33,33 \\
\hline 5. & 8,67 & 2 & 6,66 \\
\hline \multicolumn{2}{|c|}{ Jumlah } & 30 & 100,00 \\
\hline
\end{tabular}

Walaupun ada peningkatan hasil belajar pada siklus I ini namun pendekatan dalam pembelajaran dianggap masih kurang optimal sehingga siswa kurang aktif dan masih ribut sewaktu pembelajaran sedang 
berlangsung. Hal ini disebabkan oleh kurang adanya pengalaman guru dalam mengajar. Dilihat dari lembar observasi dan hasil belajar siswa yang masih tergolong rendah. Maka penelitian ini dilanjutkan ke siklus II yang bertujuan untuk mengoptimalkan penerapan pendekatan Contextual Teaching Learning dalam pembelajaran agar indikator keberhasilan dapat tercapai dengan baik yang dapat dihat dari nilai postes pada siklus II yang dapat dilihat pada Tabel 3.

Tabel 3. Nilai Postes Siklus II

\begin{tabular}{|c|c|c|c|}
\hline No & Nilai & $\begin{array}{c}\text { Jumlah } \\
\text { Siswa }\end{array}$ & Ketuntasan \% \\
\hline 1. & 4,67 & 1 & 3,33 \\
\hline 2. & 6,00 & 13 & 43,33 \\
\hline 3. & 7,34 & 6 & 20,00 \\
\hline 4. & 8,67 & 3 & 10,00 \\
\hline 5. & 10,00 & 7 & 23,33 \\
\hline \multicolumn{2}{|c|}{ Jumlah } & 30 & 100,00 \\
\hline
\end{tabular}

\section{PEMBAHASAN}

Berdasarkan temuan guru yang telah diuraikan, pelaksanaan pembelajaran pada pokok bahasan memahami konsep kalor dengan menggunakan pendekatan CTL dalam proses pembelajaran menciptakan suasana aktif bagi siswa.

Dengan menggunakan pendekatan $C T L$ ini siswa dapat lebih fokus dan bersemangat dalam belajar karena pada pembelajaran $C T L$ materi pelajaran dihubungkan dengan situasi nyata siswa sehingga siswa semakin aktif dalam belajar.

Pelaksanaan pembelajaran dengan menggunakan pendekatan CTL dalam proses pembelajaran sudah terlaksana secara optimal. Dikatakan optimal karena langkah-langkah penerapan pendekatan Contextual
Teaching Learning sudah terlaksana sepenuhnya pada tahap tindakan. Sehingga hasil belajar siswa dikatakan meningkat mulai dari pre test (tes awal), pos tes I dan pos tes II. Hal tersebut dapat dilihat dari nilai ratarata kelas dan peningkatan persentase siswa mengalami ketuntasan belajar yang dapat dilihat pada Tabel 4 .

Tabel 4. Hasil Belajar Siswa dari Pre Test, Post Tes I dan Post Tes II.

\begin{tabular}{|c|c|c|c|}
\hline Kode Siswa & $\begin{array}{c}\text { Pre test } \\
\text { Nilai }\end{array}$ & $\begin{array}{c}\text { Post test } \\
\text { I }\end{array}$ & $\begin{array}{c}\text { Post test } \\
\text { II }\end{array}$ \\
\hline 1 & 0,67 & 3,34 & 4,67 \\
\hline 2 & 2,00 & 4,67 & 6,00 \\
\hline 3 & 2,00 & 3,34 & 7,34 \\
\hline 4 & 0,67 & 4,67 & 6,00 \\
\hline 5 & 2,00 & 6,00 & 7,34 \\
\hline 6 & 6,00 & 8,67 & 10,00 \\
\hline 7 & 0,67 & 4,67 & 7,34 \\
\hline 8 & 2,00 & 4,67 & 7,34 \\
\hline 9 & 6,00 & 7,34 & 8,67 \\
\hline 10 & 4,67 & 7,34 & 8,67 \\
\hline 11 & 0,67 & 3,34 & 6,00 \\
\hline 12 & 3,34 & 7,34 & 10,00 \\
\hline 13 & 0,67 & 4,67 & 6,00 \\
\hline 14 & 7,34 & 7,34 & 10,00 \\
\hline 15 & 2,00 & 6,00 & 8,67 \\
\hline 16 & 3,34 & 6,00 & 7,34 \\
\hline 17 & 6,00 & 7,34 & 8,67 \\
\hline 18 & 2,00 & 4,67 & 7,34 \\
\hline 19 & 0,67 & 3,34 & 8,67 \\
\hline 20 & 3,34 & 4,67 & 6,00 \\
\hline 21 & 3,34 & 4,67 & 7,34 \\
\hline 22 & 6,00 & 7,34 & 8,67 \\
\hline 23 & 2,00 & 3,34 & 6,00 \\
\hline 24 & 6,00 & 7,34 & 10,00 \\
\hline 25 & 7,34 & 7,34 & 10,00 \\
\hline 26 & 4,67 & 7,34 & 8,67 \\
\hline 27 & 3,34 & 4,67 & 7,34 \\
\hline 28 & 7,34 & 8,67 & 10,00 \\
\hline 29 & 2,00 & 3,34 & 7,34 \\
\hline 30 & 4,67 & 7,34 & 8,67 \\
\hline Jumlah & 102,75 & 170,81 & 222,72 \\
\hline Rata-rata & 3,42 & 5,69 & 7,42 \\
\hline Ketuntasan & $10 \%$ & $33,33 \%$ & $76,6 \%$ \\
\hline
\end{tabular}


Hal ini berarti adanya peningkatan aktivitas mahasiswa dalam proses pembelajaran dikarenakan siswa merasa senang dalam mengikuti pelajaran ini. Adanya aktivitas siswa yang positif akan sangat mendukung terhadap peningkatan kualiatas pembelajaran siswa, karena bila aktivitas meningkat, berarti siswa termotivasi untuk mempelajari materi yang disajikan dan akan mampu menjawab berbagai pertanyaan ataupun menyelesaikan soal-soal yang diberikan, yang tentunya akan mampu meningkatkan pemahaman terhadap proses pembelajaran yang disajikan yang pada akhirnya akan meningkatkan hasil belajar siswa. Adanya peningkatan hasil belajar siswa ini tentu saja akan menimbulkan kepuasan siswa terhadap materi pelajaran yang disajikan.

Dari hasil pengamatan tindakan yang dilakukan guru penggunaan pendekatan Contextual Teaching Learning dalam pembelajaran pada pokok bahasan memahami konsep kalor yang dilakukan dalam pembelajaran sudah dikatakan optimal. Dapat dilihat bahwa adanya peningkatan hasil belajar dibandingkan dengan hasil belajar pada pre tes dan pos test siklus I, dimana pada siklus II ini nilai ratarata yang diperoleh siswa mencapai 7,42 (23 orang) dikatakan sudah tuntas dalam belajar. Dengan demikian, pada siklus II ini telah mencapai ketuntasan secara optimal, sehingga tidak perlu melakukan tindakan pembelajaran ke siklus berikutnya dimana rekapitulasi hasilnya dapat dilihat pada Tabel 5 berikut ini.

Tabel 5. Rekapitulasi Hasil Penelitian mulai dari Pre Tes, Pos Test I, dan Post Tes II

\begin{tabular}{|c|c|c|c|}
\hline Aspek & $\begin{array}{c}\text { Jumlah } \\
\text { Siswa }\end{array}$ & $\begin{array}{c}\text { Nilai } \\
\text { Rata- } \\
\text { Rata }\end{array}$ & Ketuntasan \\
\hline Pretes & 3 & 3,51 & $10,00 \%$ \\
\hline $\begin{array}{c}\text { Postes } \\
\text { siklus I }\end{array}$ & 10 & 5,69 & $33,33 \%$ \\
\hline $\begin{array}{c}\text { Postes } \\
\text { siklus I }\end{array}$ & 23 & 7,42 & $76,60 \%$ \\
\hline
\end{tabular}

\section{KESIMPULAN}

1. Dengan menerapkan pendekatan Contextual Teaching Learning pada materi mendiskripsikan konsep kalor di kelas X-III SMA Negeri 12 Medan dapat meningkatkan hasil belajar siswa. Mulai dari tes awal sampai postes siklus II. Pada tes awal sebanyak 3 orang siswa (10\%) yang tuntas dalam belajar dengan rata-rata 3,42. Pada siklus I sebanyak 10 orang siswa $(33,33 \%)$ yang tuntas dalam belajar dengan rata-rata 5,69. Pada siklus II sebanyak 23 orang siswa $(76,6 \%)$ yang tuntas dalam belajar dengan rata-rata 7,42 .

2. Pendekatan Contextual Teaching Learning mengaitkan materi pelajaran dengan lingkungan sekitar siswa sehingga mendorong siswa membuat hubungan antara pengetahuan yang dimilikinya dengan penerapannya dalam kehidupan sehari-hari mereka. Siswa dalam belajar tidak hanya sekedar menghapal atau mengingat fakta karena itu akan mudah dilupakan siswa. 


\section{DAFTAR PUSTAKA}

Arikunto, S., (2006), Prosedur Penelitian: Suatu Pendekatan Praktik, Rineka Cipta, Jakarta.

Arikunto, Suharjono dan Supriadi, 2006, Penelitian Tindakan Kelas, Jakarta. Bumi Aksara.

Arikunto, S., 2006, Dasar-Dasar Evaluasi Pendidikan, Bumi Aksara, Jakarta.

Djamarah, B., S., dan Zein, A., 2006, Stategi Belajar Mengajar, Jakarta: PT Rineka Cipta.

Slameto, 2010, Belajar dan FaktorFaktor yang Mempengaruhinya, PT. Rineka Cipta, Jakarta.

Jhonson, E., B., 2009, Contextual Teaching and Learning, Bandung: MLC. Cet. Ke-VIII 